\title{
THE ROLE OF ADVERTISING IN SHAPING CHILDREN'S PREFERENCES OF CONSUMPTION
}

\author{
B. Hoffmann* \\ Institute of Applied Social Sciences, University of Warsaw, Poland
}

\begin{abstract}
The society of "Western civilization" is a consumer society. A special role belongs here to the media, which have become an inseparable element in the life of a modern man. Their universality, as well as rapid development have caused that they deeply penetrated various areas of social life, becoming available not only for adults but also for children from their early age. The life of contemporary children is very strongly associated with the mass media, and the media have become an extremely important link in the process of socialization. The range and influence of the media are not only growing, but they are also completely different than they used to be. In addition to many functions that the media meet, they are also an important carrier for advertising. Children and young people can be both the recipients of the advertisement and its active participants. More and more advertising messages are directly or indirectly addressed to minors. Advertising affects an important cognitive sphere of a child and its interpersonal and social relations. A child left on the impact of advertising, accepts its content uncritically. This leads to the formation of many defective and, unfortunately, lasting beliefs that affect the formation of a child's personality, the system of beliefs and values. The following text aims to present, based on the literature of the subject, a broad spectrum of advertising impact on a child, with a particular emphasis on television advertising. My assumption is to show the problem from the perspective of social sciences, including sociology. For this reason, I am not concentrating only on the psychological dimension of the phenomenon but I am also trying to outline important aspects of sociocultural reality in which the process of socialization of child consumption takes place.

This is a review article. The basis of the scientific workshop is the research - analysis of the secondary media with regard to reports, publications, newsletters, catalogues and information relating to the influence of media on consumer behavior of children, both in Poland and in some western societies in the world. I hope that the article will help to draw attention to the problem not only of the communities involved in psycho-social aspects of a child's development, but will also increase public awareness of the impact of media advertising on children.
\end{abstract}

Key words: advertisement, child, consumption, advertising spot, advertising message, consumer

\section{INTRODUCTION}

The society of the so-called "Western civilization" is a consumer society and it is difficult to deny that. A special role here is played by the media which convince consumers that constant satisfaction of needs is not only the most important but also the easiest goal of life. Although consumer needs, according to Baudrillard, do not have much in common with satisfying natural needs, the

\footnotetext{
*Correspondence to: Dr. hab. Beata Hoffmann, Institute of Applied Social Sciences, University of Warsaw, Poland, hoffmann.beata@gmail.com
}

constant act of consumption becomes the main goal of human beings. What is important, the consumer has lost the ability to dominate the subject, has become a passive party in the subject-object relationship. Those are the things that choose customers, those are the goods that search for their buyers, and those are the items that identify the consumer. The value given to advertising messages with the appropriate emotional color suggests that the only thing worthy of interest is the subject of consumption (1). These changes in the meaning and position of consumption are to a great extent related to the change in values that 
are determinants of culture. And culture has a unique influence on people's consumer behavior, including young people and children.

\section{ADVERTISING - GENERAL CHARACTERISTICS}

It is difficult to clearly indicate the beginnings of advertising, but it can be assumed that the first action associated with the creation of classical advertising was the exchange of goods in antiquity. Along with a development of a market, people felt the excess of certain products that they wanted to sell or replace. Sales support activities were initiated to inform buyers about the possibility of buying a specific product or making use of the service. These were done by loud calls in the streets, on fairs and markets. Hence, the term advertising is, in many languages like Polish for instance (reklama), derived from the Latin word reclamare, which means calling, shouting to someone, contradicting, exhorting, knocking, making a noise (2). As Marzena Lemanowicz notes, it is different with the English equivalent of the word advertising - it comes from the Latin adverte. It is translated as "to proclaim, to attract attention, to turn away". This applies in principle to messages published in the press, which due to their attractiveness stands out among other press releases (3).

The flourishing and professionalization of marketing activities fall on the second half of the nineteenth century and the twentieth century and especially on the period of the emergence and dissemination of mass culture. The advertisements, which until then had a rather local character and took the form of simple notices, turned out to be insufficient, did not fulfill their functions. There has been a rapid transition from the traditional, not complicated advertisements, typical of the premarketing era to fanciful, based on the achievements of cognitive psychology, advertising messages known for example from today's television. This process was associated with the emergence of mass production which was supported by the introduction of new inventions, the emergence of large corporations and a middle class interested in consumer goods. The era of research on the improvement and professionalization of media coverage has begun (4).

According to the other researchers, there were three basic factors that influenced the development of advertising: development of trade and exchange of goods, creation and development of various mass communication media, and improvement of methods and techniques of persuasion (5).

Pursuant to the oldest officially adopted definition coming from 1932, advertising is "the dissemination of information about services and goods in order to influence the formation of supply and demand" (6). According to the definition of the American Marketing Association dated from 1948, the advertisement is any paid, impersonal form of presenting and supporting goods, services or ideas by a specific broadcaster (7). Although, in line with many opinions (8), this definition is one of the most popular, defining the contemporary advertising is not a simple task as it falls under constant change, embracing more and more areas of human activity. Philip Kotler, characterizing the advertisement, says that it is the use of paid media by a seller to send convincing information about his products, services or organization (9). Its development shapes both technological and social changes.

It is worth adding that both a shape of the definition and perception of various aspects of advertising are conditioned by a wide field of interest in advertising. It covers such disciplines and fields of knowledge as, for example: psychology, sociology, cultural anthropology, economics, linguistics or law.

\section{THE MAIN GOALS OF ADVERTISING}

Advertising is one of the types of marketing strategy and its place in the broadly understood social life is undeniable. The goals of advertising are not limited to information about a product, its advantages and benefits for a consumer. Advertising contains elements of influence on a person, whose aim is to shape a favorable attitude towards a product, encourage its purchase, as well as a frequent reminder of existence of a given commodity (10).

According to Kotler, advertisement has three basic functions. The first is the information function: the advertising task is to inform a market about new products or to describe services provided by the entrepreneur. The second task of advertising is to encourage a potential customer to purchase a product or service by building his brand awareness. It may also be based on encouraging him to change the previously preferred brand to the one that is presented in the advertisement. The third task of advertising comes down to 
reminding a customer that a product may be needed in the near future (11).

Advertising that fulfills its proper function is professional, credible, clear, and what is the most important, properly read. However, from the point of view of the psychology of advertising, it becomes effective when it makes a client buy a given product (12).

\section{TYPES OF ADVERTISING}

Based on the criterion of the medium of transmission, one can distinguish: popular press advertising, more and more popular in recent years Internet advertising, TV and radio advertising, mobile advertising realized via mobile devices, outdoor advertising, nonstandard ambient usually performed on a client's special request or a cinema advertisement (13).

The most important types of advertising include: prestige advertising, social advertising, comparative advertising and hidden advertising. The first of these is to emphasize the exceptional importance of the company, its market position and the unique, distinguished on the background of the competition, character of its products and services. The purpose of social advertising is to promote certain socially desirable behavior or warn against threats. Comparative advertising is a type of advertising in which an advertising message refers to a product or service offered by a competitor. This type of advertising usually directly compares a given brand with another one, based on a comparison of mutual features and benefits of a product for a potential buyer. Then, a hidden advertisement, which may take a form of a subliminal advertisement as well as a way of presenting articles and services, consisting in the seemingly accidental insertion of a good or brand into a story of a movie, TV series or press. This advertisement may influence the recipient's decision and encourage him/ her to buy a good or service under the influence of a deliberately designed advertising message containing untrue information on facts or services (14).

\section{THE INFLUENCE OF ADVERTISING}

Advertising reaches broadly understood motivations of its recipients. Although the content of the advertising message contains both rational and emotional elements, the operation of the contemporary advertising message is focused not so much on the transfer of relevant information about a product, but rather on arousing appropriate emotions in the recipient.

As noted by Anna Kozłowska (15), contemporary advertising interacts in three dimensions: cognitive, emotional and behavioral. In the cognitive sphere, advertising primarily seeks to draw attention of the recipient so that he becomes interested in a product. For this purpose, the advertising message provides us with specific product information; more and more often this information is reduced to the product's brand or to show its special properties or applications. In order to relate a product to the life of the recipient, creators of ads use fragments of reality, properly prepared for needs of the advertising message and combine them with buying and using products. Here the fundamental question arises as to whether the advertisement reflects social reality, thus the advertisement shows a very simplified world, often schematic, reduced to stereotypes that evoke specific emotional and cognitive associations in the recipient. On the emotional level, advertising primarily seeks to strongly connect the recipient to the product. The influence of advertising in the cognitive and emotional sphere is mutually conditioning. On the behavioral ground in turn, effects of impact on the cognitive and emotional spheres of a human being are cumulative, as a result of which the influence of a simplified approach to reality, combination of use of products with specific emotions on attitudes and behaviors may be activated (16).

The reception of advertising and its influence is certainly dependent on a child's age and, consequently, on a degree of its emotional and cognitive development. Although the order of stages of socialization is constant, the boundaries of successive periods of psychological development are conditioned by many factors. As Renata Bazylik and Anna Parzonko emphasize, "a child's development from his birth to maturity - both physically and mentally - goes very differently. However, there are similar and characteristic features for particular periods of a child's life, called the characteristics of age." (17). Recalling the concept of Maria Żebrowska, distinguishing five developmental periods: infancy (first year of life), age of toddlers (from 1 to 3 years), pre-school age (from 3 to 7 years), younger school age (from 7 to 11-12 years) and age of adolescence (from 12-13 to 17-18 years) (18). 
Adults, despite their already shaped views and attitudes, are also repeatedly influenced by advertisements. On the other hand, children are the most desirable group of recipients for advertisers. Shaping attitudes is mostly possible at youngest consumers who do not yet have a good knowledge of products available on a market.

\section{TV ADVERTISEMENT}

A life of contemporary children and youth is very strongly associated with the mass media, especially with television. Research conducted by Interactive Research Center shows that over 95\% of children watch TV almost every day. In contrast, over $88 \%$ of parents expect television programs to be safer for their children, with less aggressive and vulgar content. The most-watched programs are fairy tales $(88 \%)$, educational programs $(51 \%)$ and films (41\%) (19). TNS OBOP research also indicates that the average Polish child spends two and a half hours a day in front of the TV, and on Saturdays over three (20). The reception of television programs by a child begins in a family home and lasts throughout the childhood and youth. It is not surprising then that the most popular form of marketing treatments are advertising spots in mass media (21). The popularity of television as an advertising medium is influenced by its wide range of reception by consumers and greater ability to attract an attention of a viewer as it combines both image and sound. In addition, TV advertising, contrary to popular opinion, is perceived as a reliable source of information by a large part of a society (22).

TV advertising is the most popular form of advertising not only in Poland. It is characterized by the most active options of influence and a society devotes the most time to it. Television commercials stand out above all with dynamics that cannot be used in other media; only the Internet indicates comparable possibilities. I would like to emphasize here that despite dynamic development of the Internet, television is still the most popular advertising medium.

The most common forms of advertising and public relations techniques using the television medium include spots, sponsoring and product placement. Spot is an advertising film, presented in an advertising block, specifically separated from other broadcasts by a distinctive characteristic message (23). These are spots that have the greatest impact on a young viewer. The TV spot is characterized by three properties: image, word message and sound effects. The basic meaning, not only for children have visual elements, not the context of the message. It is image that has the greatest impact on emotions of a recipient, especially of children who are more interested in colors and animated effects. The sound base together with musical effects increase the effectiveness of TV commercials, children very happily repeat simple and melodically incorporated into the message, mottos and advertising slogans (24).

\section{ADVERTISING AND A CHILD: A CHILD AS THE RECIPIENT OF AN ADVERTISEMENT}

The impact of TV advertising on children has been studied in many aspects. It is enough to mention the research work of such scientists as L. Carlson and S. Grossbart, C.K. Atkin, S. Roper and B. Shah, K. Chan, or M.E. Goldberg and G.J. Among Polish researchers, one should certainly mention the research achievements of E. Bromboszcz, P. Kossowski and E. Kasztelan. Children and young people can be recipients of an advertisement and as well its active participants. At this point, I want to concentrate on the first situation. Advertisements affect contemporary children from first years of their lives (25). Recognizing a child as an important figure on a market of commercial goods, Mateusz Halawa calls "commercialization of childhood" (26).

The advertising industry is interested in children for three main reasons: firstly, children are so-called the primary market, i.e. they themselves do shopping, and secondly they constitute the so-called influence market, and thus affect others (especially parents) to make a purchase, and finally thirdly - they constitute the future market, which in practice means that children will grow up someday and then they will be able to make even bigger purchases (27).

One can therefore speak of the triple function that children have in the "advertising theater": on one hand it is the role of a decision maker and on the other hand - the initiator of purchases, and thirdly as a direct purchaser (28).

As the research results indicate, the recipient aged 5-10 is the most susceptible to the impact of advertising films. The significant number of ads is just targeted to this age group. Even if they are not addressed directly to a child, it 
comes to the instrumental use of a child on a way to the adult clients as parents are (29).

Children have become a very easy prey in a powerful, manipulated by adults' world of consumption. Advertisers directing their message to the youngest group of viewers have already developed techniques of influencing a child's psyche and influencing their behavior. Advertisements for children are colorful, energetic, cheerful, with jolly music in the background and definitely louder than other programs. You can notice there many characters from fairy tales and other children who enjoy the product and encourage small viewers to try it out, due to the fact that - at least at the beginning of their lives - they accept all the perceived elements as real. Most children, due to their age, do not yet have the ability to critically receive the reality and that is why they are unable to determine exactly what is true and what not (30) is. For them, the world created in advertising messages is as real as the world from their closest surroundings. This is not surprising because one of the known ways of shaping children's attitudes is interweaving in an advertising message, the real world with the fictitious one. It is a unique, fairy-tale world that encourages you to buy and consume many equally unusual products. This type of advertising contributes to the change in consumer attitudes of children, as well as to children's demand to buy the advertised product. This condition is confirmed by research, as it turns out that as many as $80 \%$ of children want an advertised product and $68 \%$ encourage parents to buy it (31).

A child is treated here instrumentally as an intermediary link between an advertiser and an adult consumer. It is all the more unethical because children's recipient of advertising approaches the advertising offer more emotionally than rational. The same is easier to smuggle hidden content and manipulate a child.

Marketing specialists through advertising not only strengthen but also create childhood desires, linking a child with advertising heroes in a wider dimension. A great example is a strong link between the film industry and the sphere of advertising and the situation when almost every cartoon from film production companies like Walt Disney Animation Studios and Pixar Animation Studios involves promotion of the enormous number of toys, gadgets, CDs, school accessories or elements of clothing which refer to heroes of movies.
These companies, on the other hand, affect consumer preferences of children as well as parents' decisions on purchase.

Devoting extensive research to the economic socialization of children (32) with development of a child, a confidence in advertising decreases and the ability to notice not only a clear but also a hidden goal, gradually increases.

As it results from most studies, children demonstrate an excellent knowledge of a content of advertisements: they perfectly reproduce from their memory a content of advertising films, names of products; they take in and identify advertising slogans, remember and recognize the musical background of advertising films. The best they learn advertisements of sweets, toys and cleaning products (33). What is interesting, children demonstrate knowledge of both TV commercials addressed to them as well as to adults (34).

The world of advertising also very accurate meets needs and expectations of teenagers, therefore advertisers create an idealized vision of the world in which people live happily, in health, are beautiful and all these because they use products presented in an advertisement. Many times advertising is aimed at shaping the conviction that owning a given product becomes a (false) form of the manifesto of individuality or detachment from the reality. This is especially the case for young people trying to meet certain trends and fashions (35).

\section{THREATS AND LEGAL ASPECTS OF PROTECTING CHILDREN FROM THE NEGATIVE EFFECTS OF ADVERTISING}

According to the Code of Ethics for Advertising (2018), the value of products offered in advertising directed to children or adolescents cannot be indicated in a way that leads children or adolescents to inaccurate perception of their real value, cannot suggest that a product is available for any household budget, cannot contain content posing risk to health or safety, cannot mislead by using the natural confidence and inexperience. Advertisements directed to children or adolescents must take into account the degree of their development and may not threaten their further physical, mental or moral development. Advertisements directed to children or adolescents must not convey the message that owning or using a product will 
HOFFMANN B.

give them a social or psychological prevalence or that not having a product will have the opposite effect.

Advertisements directed to children or adolescents cannot undermine authority of parents or other persons who have legal custody. Advertisements shall not include instructions directed to children or adolescents to persuade adults to purchase advertised products.

These regulations, however, are difficult to interpret and as a result children and school youth as recipients of advertising messages, become frequently victims of manipulation and persuasion (36).

TV commercials impose a specific lifestyle and a style of consumption on children. As Renata Bazylik and Anna J. Parzonko emphasize, advertising also affects the extremely important cognitive sphere of a child and its interpersonal and pro-social relations. A child whose parents are not able to explain that advertising does not represent a real world, accepts its content uncritically. This situation often leads to formation of many defective and, unfortunately, lasting beliefs in a child which affect the shaping of its system of values. A child also begins to build its value based on things and not on its own abilities, ties with the family and friends (37).

The image emerging from advertisements makes the imagination and feelings of young people appear as the highest value shaping direction of life aspirations, becomes a condition for prestige and group acceptance. The famous question of Erich Fromm "To Have or To Be" is replaced by "the maxim": To Have means To Be.' The advertisement strongly defines a collective and individual imagination of a young recipient, it indicates what to think to be respected in a group (38). It can be said with the absolute certainty that advertising has a huge impact on shaping a consumer's lifestyle among children and adolescents, often contributing to a negative concentration on what a child does not have, instead of satisfaction with what it has (39).

Another danger is related to biological and physical sphere of a child. Encouraged by advertising, children often choose products taking into account, above all, a pleasure associated with their view, taste and emotions unleashed while watching products advertising. Specialists believe that advertising contributes to negative changes in nutritional attitudes by the fact that advertising messages directed to children, encourage then to buy products that are often unhealthy and low in nutritional value. As Marzena Lemanowicz points out, ads targeted at children often use popular characters from fairy tales, which encourage children to buy and eat more highcalorie products (40).

Also the time that a child devotes to watching TV programs, including advertisements leads in a large extent, to reduced physical activity. This fact was noticed in Poland in the early 1960s yet. It is difficult to examine the impact of a specific advertisement on a child's psyche as advertisements act jointly and by multiple repetitions. Difficulty of research also comes from the fact that because it is all about unconscious or not fully conscious effects, they cannot be examined by using a questionnaire referring to consciousness but through more complicated techniques, e.g. projection methods (i.e. reaching unconscious motivation) and experiments with a complex strategy. Therefore, results of the research presented in the study should be treated as an attempt to draw attention to the role of advertising (in this case television) in emotional and social development of children (41).

\section{CONCLUSION}

On many occasions one can find the opinion that acquiring and accumulating material goods is now the main existential goal, the first indicator of social success and a key to happiness (42). About the modern "plague of consumption" says April Benson (43), pointing to the fact that buying has become not only a socially accepted activity, but even a required one. Abundance, accumulation, multiplicity are ones of the most striking features of modern culture. Huge department stores, with richness of preserved food, clothing, food and garment articles constitute the original landscape and geometric locus of prosperity. In that accumulation of goods there is something more than just quantity of products. This is the ostentatious presence of a surplus, an excess that is an expression of the magical and ultimate negation of the scarcity phenomenon, the motherly and luxurious conviction that we have already reached the land of happiness and abundance (44). Specific cultural norms give rise to the conviction that it is necessary to possess different goods in order to manifest someone's status. 
HOFFMANN B.

Media plays a huge role in shaping new consumer attitudes. Aggressive promotions and advertising are increasingly encouraging, also children and adolescents to do shopping. Among many factors affecting the attitude to ownership, a pressure of the reference group takes a special place. It is primarily exposed to children and adolescents who are trying to gain the approval of a specific peer community (45). The specific design of the commercial offer, usually presented in a multidimensional, having a strong stimulus value way, also contributes to be tempted to the advertising offer. Supermarkets and shopping centers have become in recent years the real "temples of consumption" (46), organizing free time for all families. They are associated, especially by children, with a place where you can play; eat "in fast food restaurants" and from where you can go out with another, new (best advertised) toy. It is the children that have become such an important "outlet market" in the last few decades so that in the United States annually 15 billion are allocated to marketing campaigns of which children are the target audience (47). A similar situation occurs in other developed countries around the world.

A man of present days is in contact with the vast amount of advertising messages and it is certainly not possible to get rid of them. The same applies to children and young people who apart from commercials received via television, are subject to the influence of online or street advertising.

The problem of an impact of advertising on children and adolescents is discussed in many studies and publications in various areas of science. A special place is occupied by the conclusions of psychologists and pedagogues. It is also important to look at the advertisement from the perspective of sociology, economics or cultural sciences.

According to previous research, TV commercials are perceived differently by children at various stages of their development. In addition to social interactions to which a child is subjected mainly in the family, TV commercials are very important factors in the socialization of child consumption (48). Ads can have an intentional and unintentional impact on children; intended - in the form of persuading them to purchase a given product, unintentionally - by causing internal conflicts, frustration and even conflicts with the environment (49).
The developmental and educational effects as well as the alleged harmfulness of advertisements evoke many critical opinions. As I have already mentioned, the influence of TV commercials is not easily prevented, therefore it seems necessary to take educational measures to mitigate their negative effects. The right action, I think, should be directed at shaping not so much the negative as the critical approach to advertising.

Analyzing the content and form of typical advertisements at children could develop their criticism and facilitate not giving in to the persuasion contained in advertising messages (50). The emphasis on the implementation of the idea of media education, in which there would be room for issues showing the mechanism of advertising spots, would increase the chance of "defending" children from the negative effects of this form of promotion of goods (51).

Discussing different dimensions of consumption in a family and at school, presenting alternative values and goals could help to change attitudes towards advertising. In discussions about the advertising message, the emphasis should be on the complexity of impact of advertising, depending on many other factors on which we can have influence as recipients (52). Not without the significance is the parents' attitude towards advertising or their consideration of shopping as a form of entertainment, prioritizing it before the actual time spent with a child.

Interesting information is provided by the results of the research of Les Carlson and Stanford Grossbart, showing the relationship between a style of upbringing preferred by parents and commercial socialization of a child in the United States (53). No less interesting are the results of almost analogous studies carried out in Japan (54).

Adrian Nowak, paying attention to the role of prevention in the fight against the destructive impact of advertising on children and adolescents, emphasizes the need to raise awareness of young people in their role of consumers and thus awareness of advertising functions and their impact on human behavior. An interesting solution is "My Consumer $A B C "$ program, created with funds of the European Union by the Office of Competition and Consumer Protection. "It has its own website, run in a child-friendly form, where in interesting and nice way, you can find out 
possible sources of help in case of becoming a victim to fraud, what are the shopping traps, what are signs and symbols appearing on products. You can also learn about other aspects of a young consumer's existing." (55). On the website of the campaign, young people can learn how advertising was actually constructed and how it operates. Thanks to an easy-to-understand explanation, a child will learn that a several seconds advertising spot is a result of weeks of work of a team of specialists, that until it is broadcast it is tested, that there are some persuasive mechanisms of advertising [56]. In the tab devoted to explaining the operation of advertisements, you can find rules addressed to children, which should be guided by watching advertisements in order to be able to consider them in a conscious manner:

- Let us have our own reason and opinion. We decide ourselves what is best for us and really needed.

- Let us take the ad with detachment. The world will never really be like in advertising. Let's remember that this is just a colorful story about a product in which everything does not have to be true.

- Do not forget that an advertisement was created in order to persuade us to something to spend our money.

-When we are in a store, let's think for a moment why choose this and not another product. Note the label and price. It may turn out that the purchase will not be so profitable for us.

- Do not believe that fashionable branded things will make us better than others, that we will gain friends and sympathy of the surroundings.

These goals are achieved by influencing the change of opinions and attitudes of young people towards advertising, deepening their knowledge about the consequences of being subject to advertising, as well as by acquiring certain skills that protect young people and even children against an uncritical attitude to advertising messages.

Recognizing the significant impact of advertising on shaping consumer preferences of children and adolescents, it is worth noting that the content circulating among children does not always confirm the opinion about passive assimilation of advertising content. In the children's environment, functioning of content taken from the mass media can often be noticed. Dorota Simonides talks about the phenomenon of shaping children's folklore through advertising (57). We are dealing here with oral messages of the content taken from the advertisement, in the unchanged form, but also in the form of their own modifications that seem to be parody or mockery. Such situations are not uncommon and may be a testimony to the existing distance, or even a manifestation of children's critical attitude towards ads they see.

At the end it is worth mentioning that advertising, despite carrying threats, also has its numerous positive aspects. This mainly applies to the so-called social advertising. Broadcasters of these advertisements raise problems important from the social point of view, stimulate reflection, sensitize, and encourage reactions and change. The content of many social campaigns enable children and young people to find important and often difficult subjects also in their immediate environment.

\section{REFERENCES}

1. Baudrillard J., Społeczeństwo konsumpcyjne. Jego mity i struktury [Consumer society. Its myths and structures], Warszawa: Wydawnictwo Sic!, 2006.

2. after: Lemanowicz M., Rola Reklamy telewizyjnej $\mathrm{W}$ kształtowaniu postaw żywieniowych dzieci w wieku szkolnym [The role of TV advertising in shaping the nutritional attitudes of school-age children], Stowarzyszenie ekonomistów rolnictwa $i$ agrobiznesu. Roczniki naukowe, tom Xvii, zeszyt 6, 2015, pp. 146-150.

3. after: Lemanowicz M., op. cit.,.

4. Russell J.T., Lane W.R., Reklama według Ottona Kleppnera [Advertisement by Otto Kleppner], Warszawa: Felberg SJA.

5. Bazylik R., Parzonko A.J., Reklama telewizyjna w opinii dzieci i młodzieży [Television advertising in the opinion of children and adolescents], Polityki Europejskie, Finanse i Marketing, 9 (58), 2013, pp. 55-65.

6. Markiewicz M., Reklama zewnętrzna w mieście [Outdoor advertising in the city], Koszalin: Wydawnictwo Uczelniane Politechniki Koszalińskiej, 2010.

7. Kotler P., Marketing - analiza, planowanie, wdrażania i kontrola [Marketing - analysis, planning, implementation and control], Warszawa: Wydawnictwo Felberg SJA, 1999.

8. Lemanowicz M., op. cit.

9. Kotler P., op. cit. 
10.Kasztelan E., Stan zareklamowania. Reklama wobec dziecka w środkach masowego przekazu [Condition of publicizing. Advertising against a child in the mass media], Wrocław: ATLA 2, 1999.

11.Kotler P., Marketing, Poznań: Rebis Publishing House, 2005.

12.Bazylik R., Parzonko A.J., op. cit. (2013).

13. Rosowska A., Wpływ reklamy na decyzje zakupowe kobiet $\mathrm{w}$ aspekcie badań własnych [The impact of advertising on purchasing decisions of women in the aspect of the own research], Zeszyty Naukowe Wyższej Szkoty Humanitas. Zarzadzanie, 2, 2012, pp. 134-154.

14.Rosowska A. op. cit. (2012).

15.Kozłowska A., Prowokowanie emocji w reklamie. Kontrowersje wokół reklamy [Provoking emotions in advertising. Controversy around advertising], paper at the scientific seminar, 2001. https://depot.ceon.pl/handle/123456789/160 6, access on: 20/04/2018

16.Kozłowska A., op. cit.

17.Bazylik R., Parzonko A.J., op. cit., p. 57.

18.Żebrowska M., Psychologia rozwojowa dzieci i młodzieży [Developmental psychology of children and adolescents], Warszawa: Wydawnictwo PWN, 1986.

19.Szymański G., Postawy dzieci wieku wczesnoszkolnego do reklamy telewizyjnej [Attitudes of early school-aged children to television advertising], Acta Universitatis Nicolai Copernici/Zarzadzanie, XLI (1), 2014, pp. 163-174.

20.Szymański G., op. cit.

21.Nowak A., Mamo, kup mi to! Czyli o reklamach dla dzieci [Mom, buy me this! That is about ads for children], Kultura Media - Teologia, 13, 2013, pp. 37-52.

22.Lemanowicz M., op.cit.

23.Strużycki M., Heryszek T., Nowoczesna reklama na współczesnym rynku [Modern advertising on the current market], Warszawa: Difin, 2007.

24. Szymański G., op. cit.

25.Nefat A., Dujmović M., Children's Advertising on Television and its Consumer Socialization: Parents' Attitudes, Ekonomska istraživanja, 25 (1), 2012, pp. 145-156.

26. Halawa M., Komercjalizacja dzieciństwa. Kosztorysowanie rodzicielstwa [Commercialization of childhood. Costing of parenthood], in: Dziecko w świecie mediów i konsumpcji [A child in the world of media and consumption], (ed). M. Bogunia-Borowska,

Kraków:
Wydawnictwo

HOFFMANN B.

Jagiellońskiego, 2006.

27. Starosta A.M., Dzieci jako adresaci i odbiorcy reklam telewizyjnych [Children as addresses and recipients of TV commercials], Kultura-SpoleczeństwoEdukacja, 2, 2012, pp. 173-188.

28.Starosta A.M., op. cit.

29. Kossowski P., Dziecko i reklama telewizyjna [Child and TV commercial advertisement], Warszawa: Wydawnictwo Żak, 1999.

30.Lemanowicz M., op. cit.

31.Litwińska K., Reklamy telewizyjne i ich oddziaływanie na emocje dzieci w wieku przedszkolnym [TV commercials and their impact on the emotions of pre-school children], Lublin: Katolicki Uniwersytet Lubelski, 2008.

32.more: Roland-Lévy C., Economic socialization: Basis for international comparisons, Journal of Economic Psychology, 11 (4), 1990, pp. 469-482;

33.Lassarre D., Roland-Lévy C. Understanding Children's Economie Socialization, in Understanding economic behavior, (ed.) K.G. Grünert, F. Ölander, Dordrecht (NL): Kluwer Academic Publishers, 1989, pp. 347-368.

34. Masiuk T. R., Reklamy w oczach dzieci [Advertisements in the eyes of children], Wychowanie w Przedszkolu, 10, 1994, pp. 586-591.

35.Kossowski P., op. cit.

36.Bazylik R., Parzonko A.J., op. cit.

37.Lemanowicz M., op. cit.

38.Bazylik R., Parzonko A.J., op. cit.

39.Bazylik R., Parzonko A.J., op. cit.

40.Kossowski P., op. cit.

41.Lemanowicz M., op. cit.

42. Sowa G., Wpływ reklamy telewizyjnej na kształtowanie osobowości uczniów szkoły podstawowej [Influence of TV advertising on shaping the personality of primary school students], Master thesis. Rzeszów: Uniwersytet Rzeszowski, 2004.

43.Szlendak T., Leniwe maskotki, rekiny na smyczy. W co kultura konsumpcyjna przemieniła mężczyzn i kobiety [Lazy mascots, sharks on a leash. In what consumer culture changed men and women], Warsaw: Jacek Santorski, 2005.

44.Benson A., To Buy or Not to Buy: Why We Overshop and How to Stop, Trumpeter, 2008.

45.Baudrillard J., op. cit.

46. Woodruffe-Burton H., Private desires, public display: consumption, 
postmodernism and fashion's 'new man', International Journal of Retail \& Distribution Management, 26 (8), 1998, pp. 301-310;

47.Mącik D., Między przyjemnościa a uzależnieniem. Psychologia zakupów nieoplanowanych [Between pleasure and addiction. Psychology of unsupported purchases], Toruń: Wydawnictwo Naukowe GRADO, 2008.

48.Ritzer G., Magiczny świat konsumpcji [The magical world of consumption], Warszawa: Muza, 2004.

49.Szlendak T., op. cit.

50.Bromboszcz E., Rola reklamy telewizyjnej w procesie socjalizacji konsumpcji u dzieci [The role of TV advertising in the process of socialization of consumption in children], Chowanna, 1, 1994, pp. 32-41.

51.Bromboszcz E., Percepcja reklamy telewizyjnej przez dzieci [Perception of television advertising by children], Psychologia Wychowawcza, 1, 1993, pp. 60-66.

52.Bromboszcz E. (1993), op. cit.

53.Kossowski P., op. cit.

54.Kozłowska A., op. cit.

55.Carlson E., Grossbart S., Parental Style and Consumer Socialization of Children, Journal of Consumer Research, Volume 15, Issue 1,1988, p. 77-94.

56.Rose M. G., Dalakas V., Kropp F., Kamineni R., Raising young consumers: consumer socialization and parental style across cultures, Advances in Consumer Research, 29 (1), 2002, p. 65-65.

57.Nowak A., op. cit., p. 48.

58.after: Nowak A., op. cit.

59. Simonides D., Współczesny folklor słowny dzieci i nastolatków [Contemporary verbal folklore of children and teenagers], Wrocław: Wydawnictwo PWN, 1976. 